\title{
APLIKASI GEOSPASIAL ANALISIS UNTUK PENENTUAN ZONA IMBUHAN AIRTANAH DI CAT WONOSOBO, PROVINSI JAWA TENGAH
}

\author{
Geospatial Analysis Application for Defining Groundwater Recharge \\ Zone in Wonosobo Groundwater Basin, Central Java Province
}

\section{Thomas Triadi Putranto ${ }^{1}$, Wahju Krishna Hidajat ${ }^{1}$ dan Annita Kusuma Wardhani ${ }^{1}$}

\begin{abstract}
Abstrak: Airtanah adalah sumberdaya yang berharga untuk mencukupi kebutuhan sehari-hari manusia yang akan meningkat seiring bertambahnya jumlah penduduk. Oleh sebab itu, airtanah perlu dikelola dengan baik. Pengelolaan airtanah dapat dilakukan secara menyeluruh dalam cekungan airtanah (CAT) termasuk penentuan zona imbuhan airtanah. Penelitian ini bertujuan untuk memberikan rekomendasi untuk pelestarian airtanah di CAT Wonosobo, Provinsi Jawa Tengah melalui penentuan zona imbuhan airtanah. Penentuan zona imbuhan didapat dengan menerapkan analisis geospasial menggunakan pembobotan dan pendekatan skoring. Metode ini dicapai dengan analisis tumpang tindih dari penilaian beberapa parameter (kelulusan batuan, curah hujan, tanah penutup, kemiringan lereng, kedalaman muka airtanah tidak tertekan) menggunakan perangkat lunak ArcGIS 10.3. Parameter yang digunakan adalah permeabilitas batuan, curah hujan, jenis tanah, kemiringan lereng, dan kedalaman muka airtanah. Hasil dari analisis geospasial dapat dibagi menjadi 2 zona, yaitu zona imbuhan dan zona lepasan airtanah.
\end{abstract}

\section{Kata kunci: Cekungan airtanah, Pengelolaan airtanah, Geospasial analisis, ArcGIS, Zona imbuhan airtanah}

\begin{abstract}
Groundwater is the valuable resources for supplying daily necessity of human's life that is going to increase in line with the increasing number of population. Therefore, groundwater needs to be well managed. Groundwater management can be done thoroughly within a groundwater basin for defining groundwater recharge zone. The groundwater recharge zone was conducted by applying geospatial analysis using weighted and scoring approach. This method was accomplished by overlaying the score of some parameters (hydraulic conductivity, precipitation, soil cover, slope, and groundwater depth of water table) using ArcGIS 10.3 software. The parameters were permeability of rocks, rainfall, soil type, slope and depth of superficial groundwater level. The result of geospatial analysis can be divided into two zones which are groundwater recharge zone and groundwater discharge zone.
\end{abstract}

Keywords: groundwater basin, groundwater management, geospatial analysis, arcgis, groundwater recharge zone

\footnotetext{
${ }^{1}$ Departemen Teknik Geologi, Fakultas Teknik, Universitas Diponegoro
} 


\section{PENDAHULUAN}

Air tanah merupakan sumber daya air yang penting dalam menunjang keperluan hidup masyarakat sehari-hari, maka keberadaan airtanah perlu dikelola dengan baik. Pengelolaan airtanah dapat dilaksanakan secara utuh dalam satu cekungan airtanah yang mencakup daerah imbuhan dan daerah lepasan airtanah. Menurut Danaryanto, dkk. (2007), daerah imbuhan airtanah dan daerah lepasan airtanah, mempunyai karakteristik hidrogeologi dan fungsi pengelolaan yang berbeda. Daerah imbuhan airtanah perlu dipelihara dan dilestarikan keberadaannya dan keadaannya, sedangkan daerah lepasan airtanah yang berfungsi sebagai daerah keluaran airtanah secara alamiah pada cekungan airtanah perlu dilakukan pengendalian dalam pengambilan airtanahnya. Kedua daerah tersebut memiliki cara yang berbeda dalam pengelolaannya maka perlu diketahui letak daerah imbuhan dan lepasan airtanah seperti pada suatu cekungan airtanah. Penentuan zona imbuhan didapat dengan menerapkan analisis geospasial menggunakan pembobotan dan pendekatan skoring (Malekmmohamadi et al. 2012; Fenta et al. 2015; Steinel et al. 2016). Metode ini dicapai dengan analisis tumpang tindih dari penilaian beberapa parameter (kelulusan batuan, curah hujan, tanah penutup, kemiringan lereng, kedalaman muka airtanah tidak tertekan) menggunakan perangkat lunak ArcGIS 10.3. Penggunaan analisis geospasial untuk pemetaan zona potensi airtanah telah banyak digunakan oleh beberapa peneliti (Nolan et al. 2003; Ganapuram, et al. 2009; Magesh et al. 2012; Manap et al. 2013; Shukla. 2014; Senayake et al. 2015; Yeh et al. 2016).

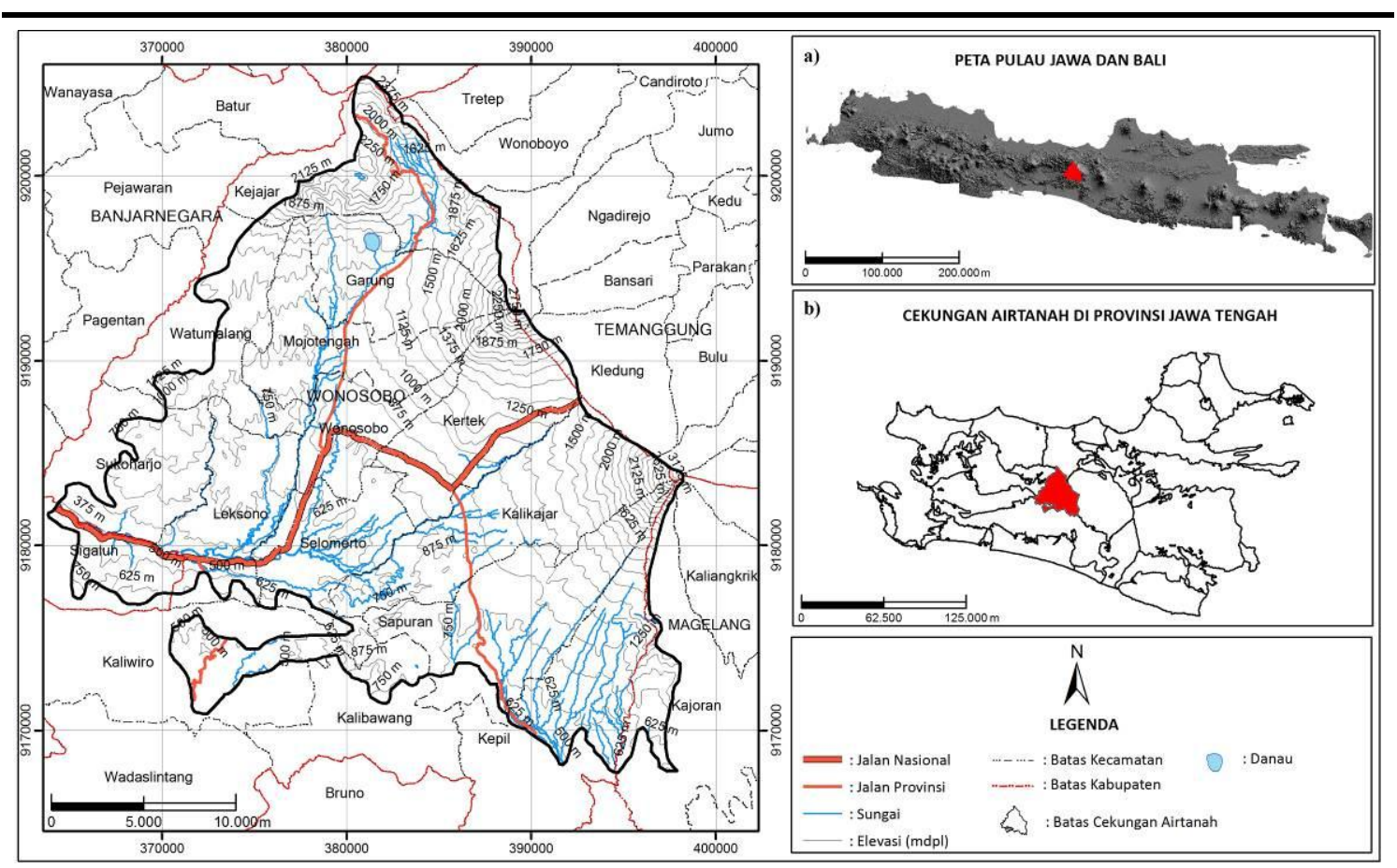

Gambar 1. Peta Indeks Lokasi Penelitian

Daerah penelitian berada di Cekungan Airtanah (CAT) Wonosobo yang tertera pada Gambar 1 meliputi sebagian besar Kabupaten Wonosobo dan sebagian kecil Kabupaten Banjarnegara serta Kabupaten Magelang dengan posisi geografis antara $7^{\circ} 10^{\prime} 47^{\prime \prime}-$ 7¹1'3" Lintang Selatan (LS) dan 109'45'46"-10945'47' Bujur Timur (BT), 
sedangkan dalam koordinat Universal Transverse Mercator (UTM) zona 49 Southern Hemisphere adalah $S$ 363424-S 398383 dan $N$ 9166882- $N$ 9206186. Lokasi ini dipilih karena untuk menjaga kelestarian daerah imbuhan di CAT Wonosobo agar kondisi sumber daya airtanah tetap dalam kondisi aman. Zonasi imbuhan dan lepasan airtanah pada CAT Wonosobo ini diharapkan dapat menjadi salah satu acuan dalam pembangunan atau dapat dimasukkan dalam perencanaan tata ruang wilayah di Kabupaten Wonosobo, sehingga tidak dapat terjadi kesalahan dalam pembangunan, misalnya pembangunan kawasan industri pada daerah imbuhan. Oleh karena itu, penentuan daerah imbuhan dan daerah lepasan airtanah perlu dilakukan untuk pengelolaan sumberdaya airtanah sesuai dengan zonasi daerahnya serta menjadi rekomendasi dalam penyusunan RTRW (Rencana Tata Ruang Wilayah) Kabupaten Wonosobo.

\section{METODOLOGI}

\section{Tahap penelitian}

Tahapan penelitian yang dilakukan terdiri dari tahapan persiapan, survey hidrogeologi dan analisis. Berikut merupakan penjabaran dari masing-masing tahapan tersebut:

a. Tahap Persiapan

Terdiri dari studi literatur untuk mempelajari konsep-konsep dasar yang berhubungan dengan penelitian dan mengetahui keadaan dan kondisi lapangan. Selain itu pengumpulan laporan ilmiah dari data sekunder berupa data geologi regional, data hasil penelitian terdahulu, data jenis tanah penutup wilayah penelitian, data curah hujan, data kelulusan batuan, dan data Digital Elevation Model-Shuttle Radar Topography Mission/DEM-SRTM (CGIAR-CSI, 2004).

b. Survei hidrogeologi

Terdiri dari tahap pengumpulan data lapangan melalui pengukuran muka airtanah dangkal, inventarisasi penggunaan airtanah litologi serta morfologi untuk selanjutnya dilakukan pengolahan data primer dan sekunder.

c. Tahap Analisis

Tahap pengolahan data dengan menggunakan metode geospasial dalam penelitian ini digunakan untuk mendeliniasi dan membagi zona imbuhan dan lepasan airtanah berdasarkan beberapa peta parameter yang digabungkan.

Tahapan penentuan zona imbuhan dan lepasan airtanah pada penelitian ini menggunakan metode pembobotan dan skoring parameter berdasarkan pada Danaryanto, dkk. (2007) yang membagi parameter klasifikasi sebagai berikut:

1) Kelulusan batuan

2) Curah hujan

3) Tanah penutup

4) Kemiringan lereng

5) Kedalaman muka airtanah tidak tertekan

Masing-masing parameter mempunyai pengaruh terhadap resapan air ke dalam tanah yang dibedakan dengan nilai bobot (Tabel 1). Parameter yang mempunyai nilai bobot paling tinggi merupakan parameter yang paling menentukan kemampuan peresapan untuk menambah airtanah secara alamiah pada suatu cekungan airtanah. 
Tabel 1. Nilai Bobot Parameter Resapan Air

\begin{tabular}{llll}
\hline No. & Parameter & \multicolumn{2}{l}{ Nilai Bobot } \\
\hline 1. & Kelulusan batuan & 5 & Sangat tinggi \\
2. & Curah hujan & 4 & Tinggi \\
3. & Tanah Penutup & 3 & Cukup \\
4. & Kemiringan lereng & 2 & Sedang \\
5. & Kedalaman muka airtanah tidak & 1 & Rendah \\
& tertekan & & \\
\hline & Sumber: Danaryanto, dkk., 2007
\end{tabular}

Peringkat parameter dibedakan berdasarkan nilai kemampuan peresapan air yang tercantum dalam Tabel 2 sampai dengan Tabel 6.

Tabel 2. Nilai Peringkat Kelulusan Batuan

\begin{tabular}{clll}
\hline No. & Nilai Kelulusan Batuan $(\mathbf{m} /$ hari) & \multicolumn{2}{c}{ Nilai Peringkat } \\
\hline 1. & $>10^{3}$ & 5 & Sangat tinggi \\
2. & $10^{1}-10^{3}$ & 4 & Tinggi \\
3. & $10^{-2}-10^{1}$ & 3 & Cukup \\
4. & $10^{-4}-10^{-2}$ & 2 & Sedang \\
5. & $<10^{-4}$ & 1 & Rendah \\
\hline \multicolumn{2}{r}{ Sumber: Danaryanto, dkk., 2007}
\end{tabular}

Tabel 3. Nilai Peringkat Curah Hujan

\begin{tabular}{clll}
\hline No. & Curah Hujan $(\mathbf{m m} /$ tahun) & Nilai Peringkat \\
\hline 1. & $>4.000$ & 5 & Sangat tinggi \\
2. & $3.000-4.000$ & 4 & Tinggi \\
3. & $2.000-3.000$ & 3 & Cukup \\
4. & $1.000-2.000$ & 2 & Sedang \\
5. & $<1.000$ & 1 & Rendah \\
\hline
\end{tabular}

Sumber: Danaryanto, dkk., 2007

Tabel 4 Nilai Peringkat Tanah Penutup

\begin{tabular}{clll}
\hline No. & Tanah Penutup & \multicolumn{2}{c}{ Nilai Peringkat } \\
\hline 1. & Kerikil & 5 & Sangat tinggi \\
2. & Pasir kerikilan & 4 & Tinggi \\
3. & Lempung pasiran/lanau pasiran & 3 & Cukup \\
4. & Lanau lempungan & 2 & Sedang \\
5. & Lempung lanauan & 1 & Rendah \\
\hline \multicolumn{2}{c}{ Sumber: Danaryanto, $d k k ., 2007$} &
\end{tabular}

Tabel 5. Nilai Peringkat Kemiringan Lereng

\begin{tabular}{clll}
\hline No. & Kemiringan Lereng (derajat) & Nilai Peringkat \\
\hline 1. & $>40^{\circ}$ & 5 & Sangat tinggi \\
2. & $20-40^{\circ}$ & 4 & Tinggi \\
3. & $10-20^{\circ}$ & 3 & Cukup \\
4. & $5-10^{\circ}$ & 2 & Sedang \\
5. & $<5^{\circ}$ & 1 & Rendah \\
\hline \multicolumn{3}{c}{ Sumber: Danaryanto, dkk., 2007, dengan modifikasi }
\end{tabular}

Tabel 6. Nilai Peringkat Kedalaman Muka Airtanah Tidak Tertekan

\begin{tabular}{clll}
\hline No. & $\begin{array}{l}\text { Kedalaman Muka Airtanah Tidak } \\
\text { Tertekan }(\mathbf{m})\end{array}$ & Nilai Peringkat \\
\hline 1. & $>30 \mathrm{~m}$ & 5 & Sangat tinggi \\
2. & $20-30 \mathrm{~m}$ & 4 & Tinggi \\
3. & $10-20 \mathrm{~m}$ & 3 & Cukup \\
4. & $5-10 \mathrm{~m}$ & 2 & Sedang \\
5. & $<5 \mathrm{~m}$ & 1 & Rendah \\
\hline Sumber: & Danaryanto, dkk, 2007 & &
\end{tabular}

Sumber: Danaryanto, dkk., 2007 
Menurut Danaryanto, dkk. (2007), klasifikasi daerah imbuhan airtanah dilakukan dengan tahapan sebagai berikut:

1) Memberi nilai bobot setiap parameter.

2) Memberi nilai peringkat setiap parameter.

3) Menjumlahkan hasil perkalian antara nilai bobot dan nilai peringkat pada setiap parameter.

4) Mengklasifikasikan daerah imbuhan airtanah berdasarkan nilai imbuhannya, yaitu menjumlahkan hasil perkalian antara nilai bobot dan nilai peringkat pada setiap parameter dengan rumus pada Persamaan 1 berikut ini.

$$
\text { Nilai imbuhan }=(\mathrm{Kb} \times \mathrm{Kp})+(\mathrm{Pb} \times \mathrm{Pp})+(\mathrm{Sb} \times \mathrm{Sp})+(\mathrm{Lb} \times \mathrm{Lp})+(\mathrm{Mb} \times \mathrm{Mp})
$$

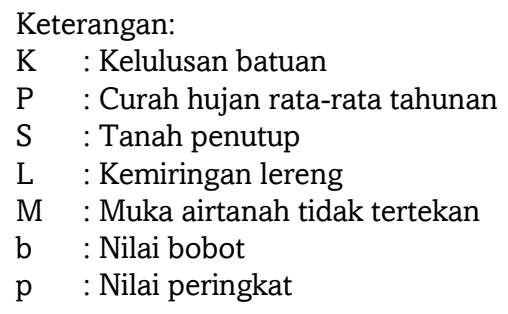

5) Pengelompokan daerah imbuhan dan resapan menggunakan klasifikasi dengan modifikasi tertera pada Tabel 7 sebagai berikut:

Tabel 7. Klasifikasi Hasil Nilai Pembobotan

\begin{tabular}{ll}
\hline Hasil Nilai Pembobotan & Jenis Daerah \\
\hline $37-54$ & Daerah Lepasan \\
$55-64$ & Daerah Imbuhan \\
\hline
\end{tabular}

Pembuatan peta zona imbuhan dan lepasan airtanah. Peta ini merupakan penggabungan dari empat peta parameter. Peta tersebut selanjutnya dianalisis kembali dengan Peta RTRW CAT Wonosobo. Hal ini untuk mengetahui kesesuaian tata guna lahan dan RTRW dengan zona imbuhan dan lepasan sehingga dapat dijadikan langkah untuk rekomendasi yang sesuai dengan fungsi daerah tersebut.

\section{HASIL DAN PEMBAHASAN}

Hasil penelitian berupa penjelasan mengenai hasil dari klasifikasi tiap parameter pembobotan dan hasil akhir dari pembobotan metode geospasial yang menunjukkan letak daerah imbuhan.

\section{Parameter Kelulusan Batuan}

Parameter kelulusan batuan ini menjadi parameter dengan nilai bobot tertinggi yaitu bernilai 5. Kelulusan batuan ini dipengaruhi oleh struktur dan tekstur dari jenis batuan tersebut. Semakin besar nilai permeabilitas dari suatu batuan, maka akan semakin besar nilai yang diperoleh. Secara umum, litologi yang ditemukan di daerah penelitian merupakan produk gunungapi seperti breksi vulkanik, tuff dan batupasir tuffan. Berdasarkan hasil pengamatan tersebut, maka daerah penelitian dapat dibagi menjadi dua daerah yaitu daerah dengan dominasi breksi yang memiliki fragmen berukuran kerikil dan daerah dengan dominasi batupasir tuffan seperti yang terlihat pada Gambar 2 . 


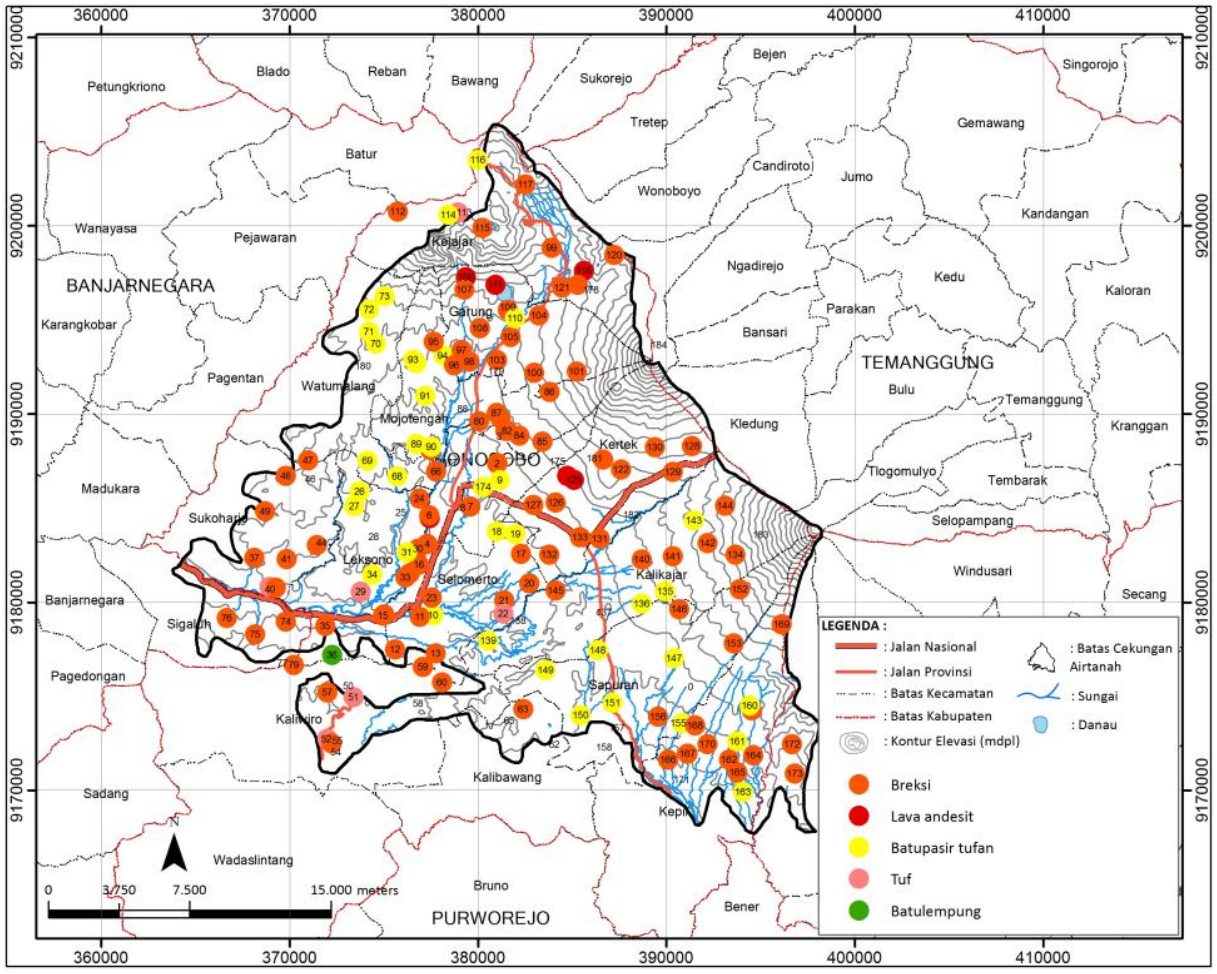

Gambar 2. Peta Titik Pengamatan

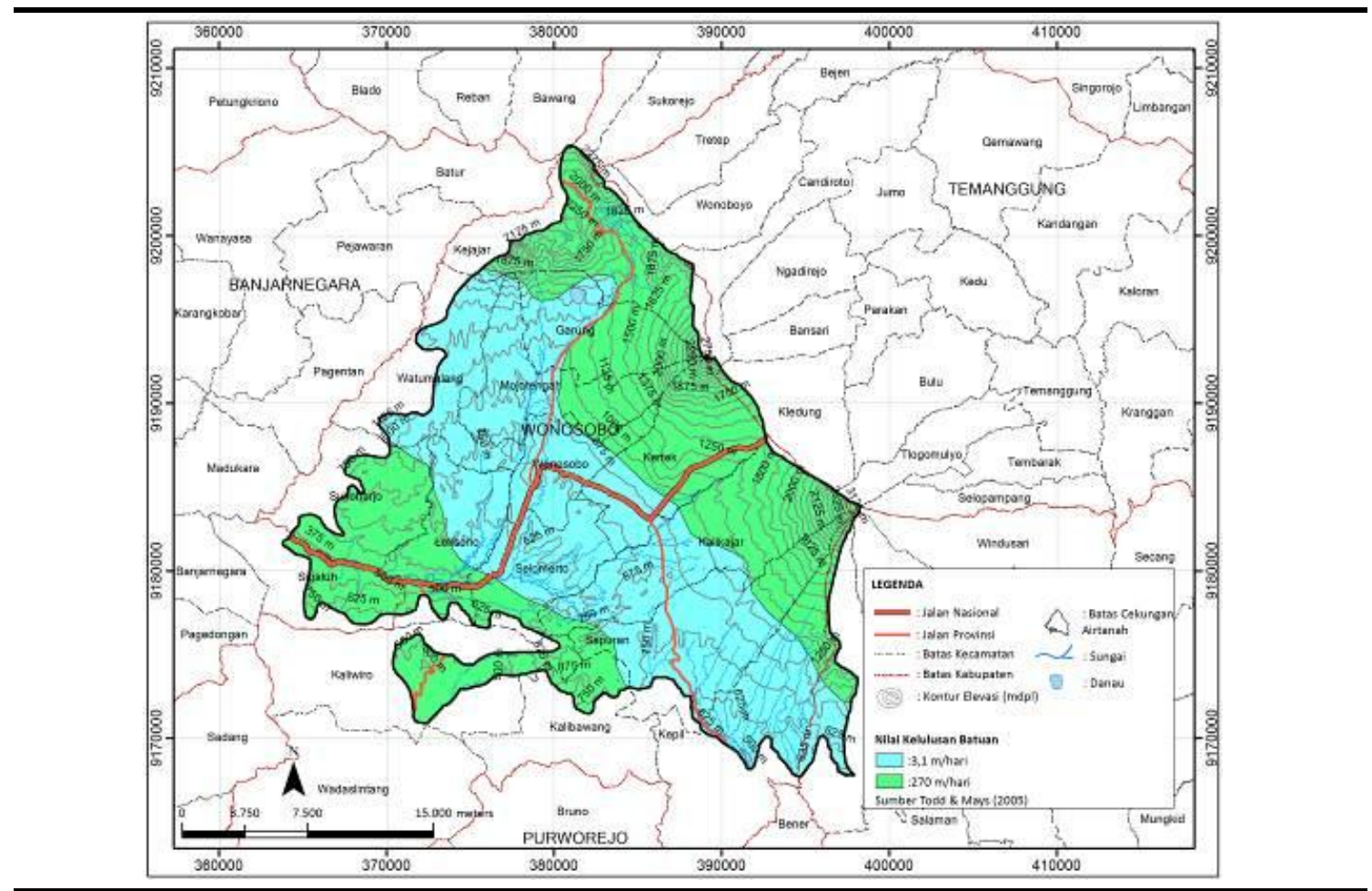

Gambar 3. Peta Konduktivitas Hidrolika 
Menurut Morris dan Johnson (1975) dalam Todd and Mays (2005) pada Tabel 8, batupasir tuffan memiliki nilai konduktivitas hidrolika batuan sebesar $3,1 \mathrm{~m} / \mathrm{hari}$. Batupasir tuffan ini diklasifikasikan sebagai batupasir ukuran sedang karena memiliki pasir dengan ukuran sedang dan bercampur dengan fragmen tuff. Daerah ini berada di bagian tengah daerah penelitian seperti yang terlihat pada Gambar 3. Daerah ini memiliki peringkat 3 dengan skor 15. Hasil deliniasi dapat dijabarkan dalam Tabel 8 berikut dan pada Gambar 4.

Tabel 8. Perhitungan Skor Parameter Kelulusan Batuan

\begin{tabular}{llll}
\hline Nilai Kelulusan Batuan (m/hari) & Nilai Peringkat & Nilai Bobot & Skor \\
\hline $10^{-2}-10^{1}$ & 3 & 5 & 5 \\
$10^{1}-10^{3}$ & 4 & 5 & 20 \\
\hline
\end{tabular}

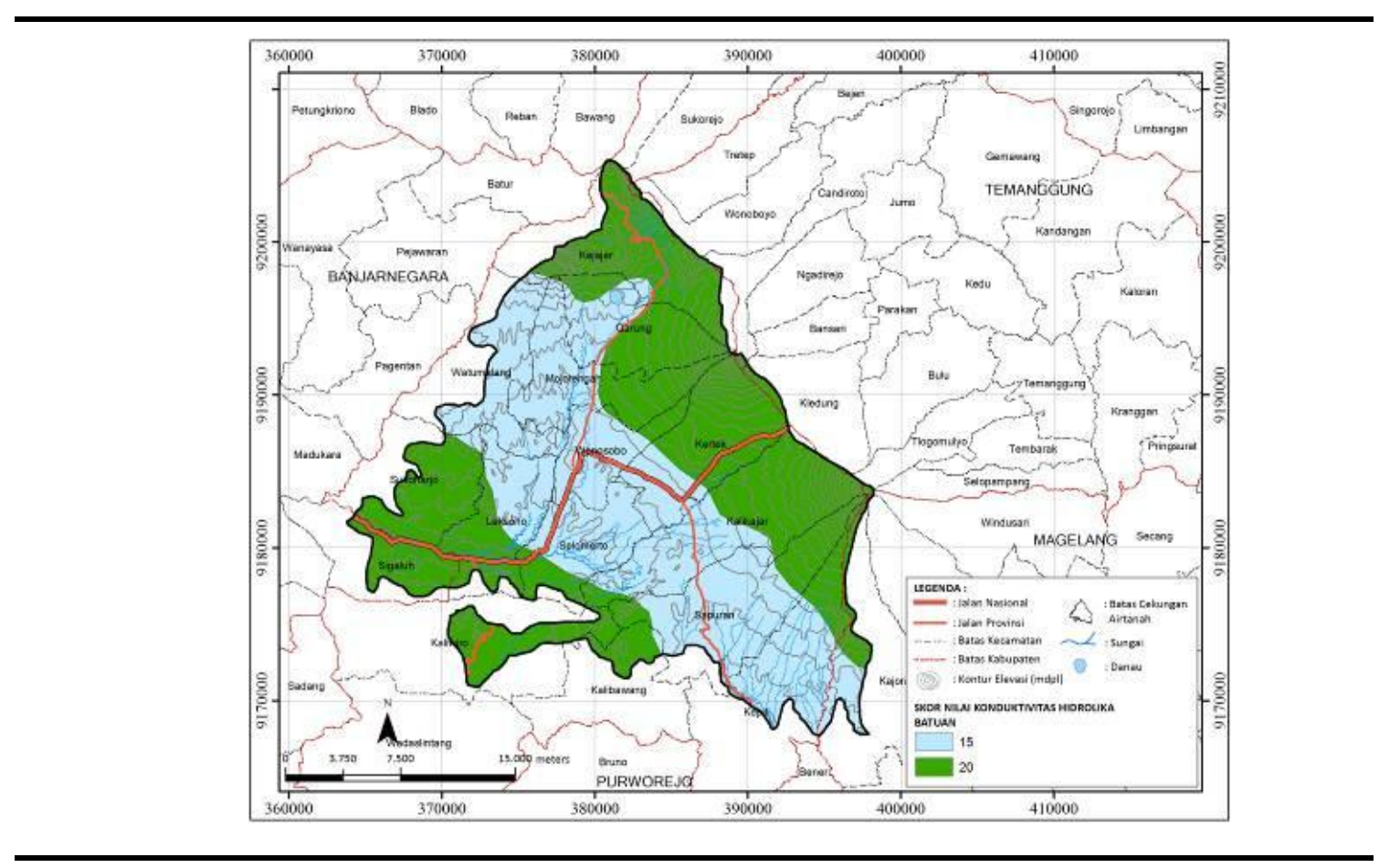

Gambar 4. Skor Nilai Parameter Konduktivitas Hidrolika Batuan

\section{Parameter Curah Hujan}

Parameter curah hujan ini menjadi parameter dengan nilai bobot yaitu empat (4) dan menjadi parameter paling berpengaruh nomor dua (2). Curah hujan akan mempengaruhi jumlah air yang masuk ke dalam tanah, dengan curah hujan tinggi maka resapan air akan semakin besar jika hujan terjadi dalam kurun waktu yang panjang. Semakin tinggi dan semakin lama curah hujan, maka akan semakin besar nilainya karena menunjukkan banyaknya pasokan air yang dapat meresap ke dalam tanah atau batuan yang mengisi lapisan akuifer dalam satu sistem cekungan airtanah. Nilai curah hujan pada CAT Wonosobo dapat dilihat pada Gambar 5.

Berdasarkan hasil klasifikasi nilai banyaknya curah hujan selama setahun, deliniasi daerah pada parameter curah hujan ini menjadi satu kelas yaitu pada rentang 3.000$4.000 \mathrm{~mm} /$ tahun yang termasuk ke dalam peringkat empat dalam klasifikasi curah 
hujan. Hal ini dikarenakan pada data penelitian menunjukkan nilai mulai 3.100 hingga $3.900 \mathrm{~mm} /$ tahun sehingga menyebabkan memiliki nilai skor yang sama yaitu enambelas (16). Perhitungan ini dapat dilihat dalam Tabel 10 dan selanjutnya disajikan dalam Gambar 6 yaitu pada peta nilai parameter curah hujan.

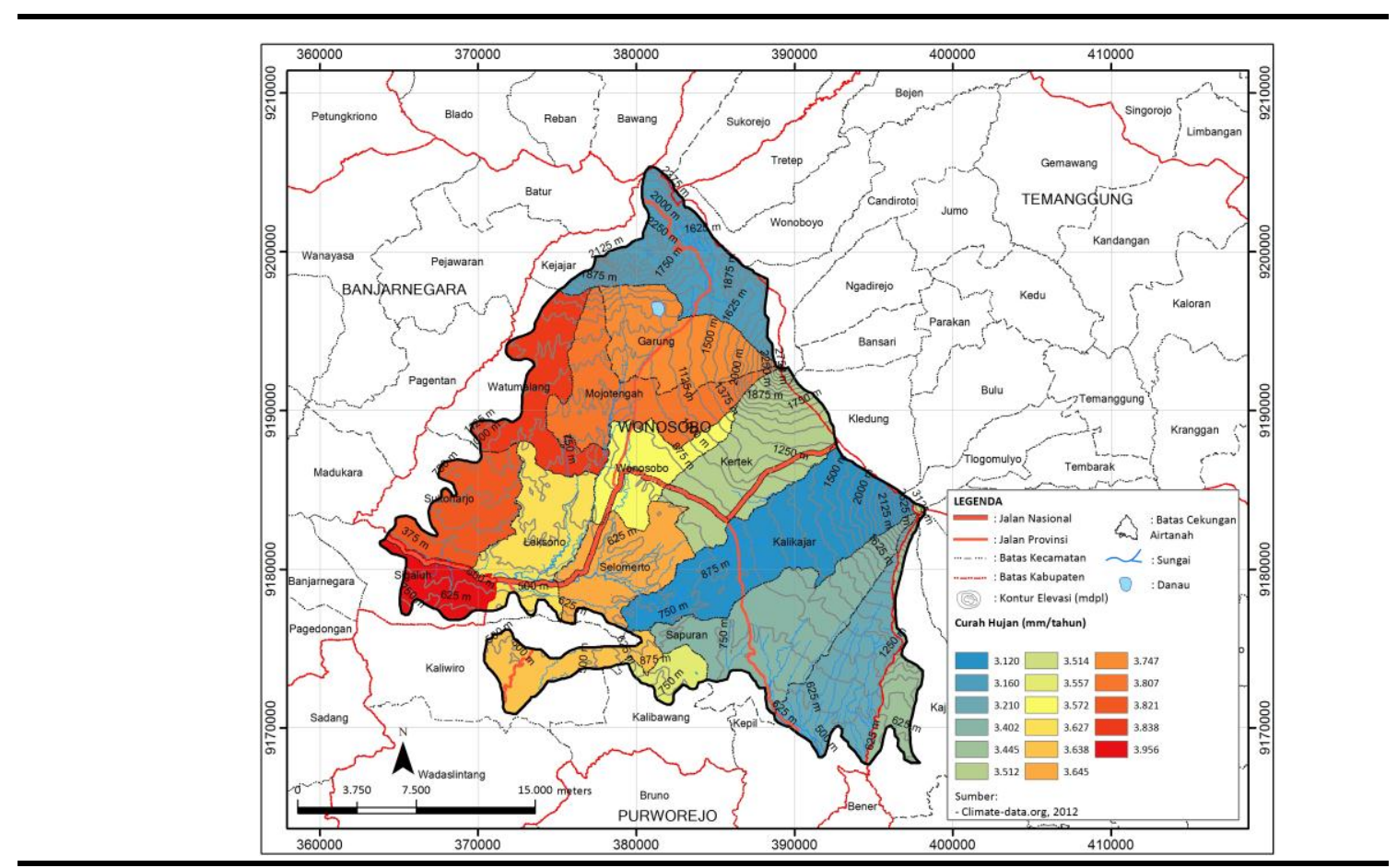

Gambar 5. Peta Curah Hujan

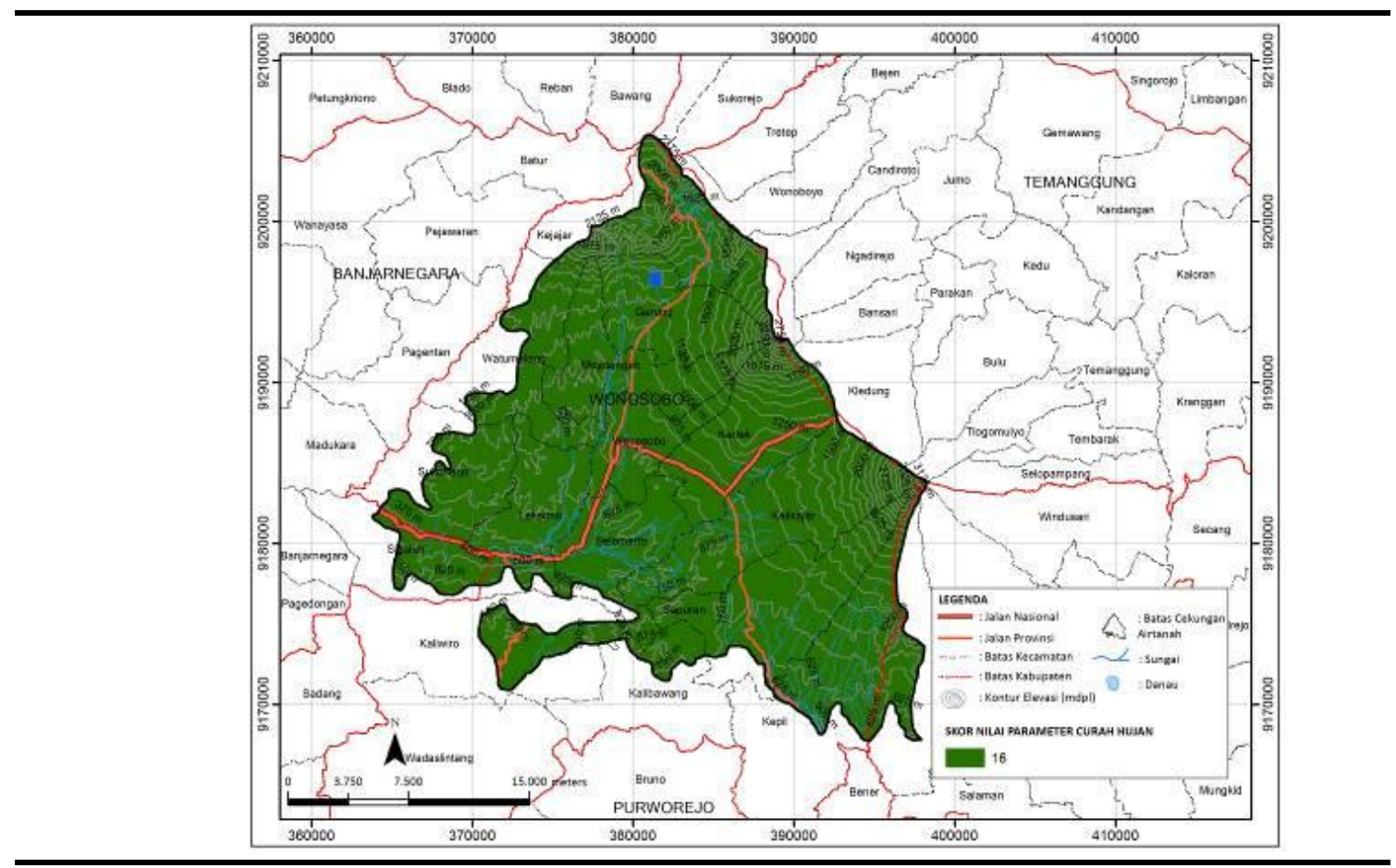

Gambar 6. Skor Nilai Parameter Curah Hujan 
Tabel 10. Perhitungan Skor Parameter Curah Hujan

\begin{tabular}{llll}
\hline Curah Hujan (mm/tahun) & Nilai Peringkat & Nilai Bobot & Skor \\
\hline $3.000-4.000$ & 4 & 4 & 16 \\
\hline
\end{tabular}

\section{Parameter Jenis Tanah Penutup}

Parameter ini dipengaruhi oleh sifat permeabilitas tanah dengan melihat kondisi butir tanah yang lebih cenderung ke lempung atau pasir. Sebaran jenis tanah penutup pada daerah penelitian dapat dilihat pada Gambar 7.

Masing-masing jenis tanah penutup pada daerah penelitian dapat membagi daerah penelitian berdasarkan tingkat banyaknya lempung pada suatu tanah. Daerah penelitian dapat dibagi menjadi tiga daerah yaitu daerah lempung lanauan, lempung pasiran dan kerikil. Lempung lanauan memiliki nilai skor 3. Daerah ini tersebar di Kecamatan Selomerto dan sebagian kecil Kecamatan Sapuran yang terdiri atas tanah latosol coklat yang bersifat seperti lempung.

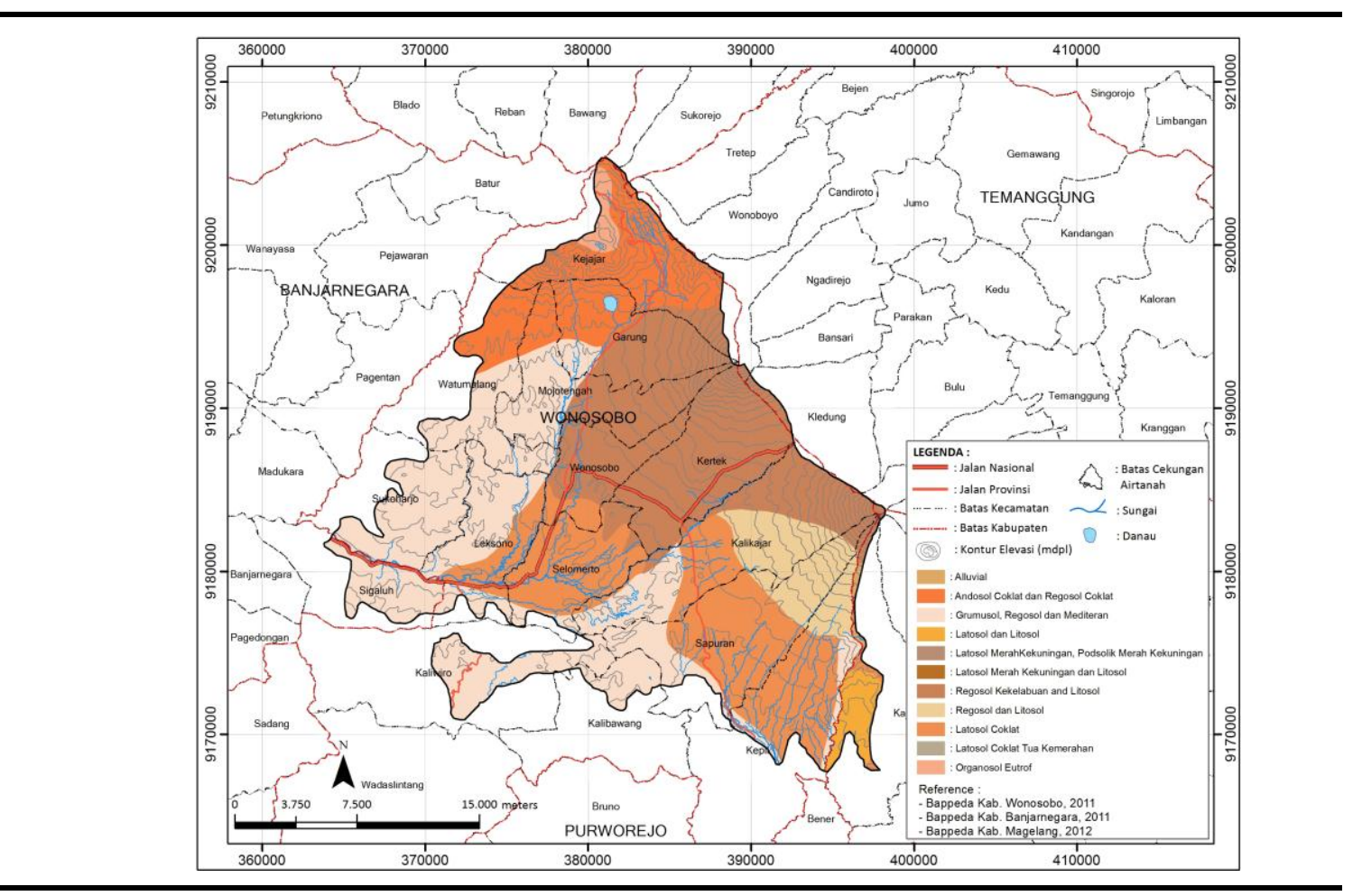

\section{Gambar 7. Peta Jenis Tanah Penutup}

Daerah lempung pasiran memiliki nilai skor 9. Daerah ini tersebar di bagian utara, barat dan selatan daerah penelitian. Daerah ini termasuk jenis lempung pasiran dikarenakan terdiri dari variasi jenis tanah seperti tanah andosol yang berasal dari tuff dan berbutir kasar seperti kerikil dan organosol yang berasal dari bahan organik serta dapat menahan air seperti lempung.

Daerah kerikil memiliki nilai skor 15 terdapat di daerah dengan morfologi puncak gunungapi hingga ke bagian lereng serta terdapat pula pada bagian tengah dari daerah penelitian. Daerah ini didominasi oleh tanah regosol yang memiliki ciri seperti berbutir 
lepas-lepas seperti kerikil dan berasal dari pelapukan batuan vulkanik. Berikut merupakan hasil perhitungan yang dapat dilihat pada Tabel 11 dan disajikan dalam Gambar 8.

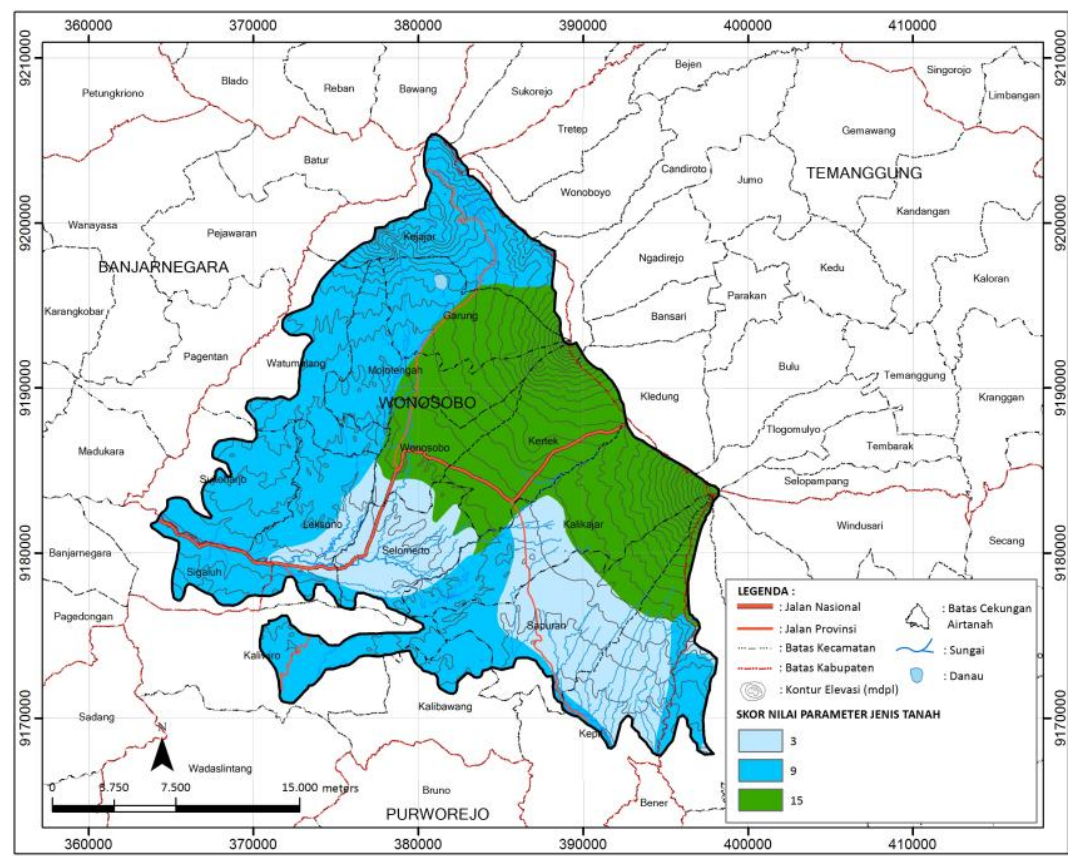

Gambar 8. Skor Nilai Parameter Jenis Tanah Penutup

Tabel 11. Perhitungan Skor Parameter Jenis Tanah Penutup.

\begin{tabular}{llll}
\hline Jenis Tanah Penutup & Nilai Peringkat & Nilai Bobot & Skor \\
\hline Lempung lanauan & 1 & 3 & 3 \\
Lempung pasiran & 3 & 3 & 9 \\
Kerikil & 5 & 3 & 15 \\
\hline
\end{tabular}

\section{Parameter Kemiringan Lereng}

Kemiringan lereng pada suatu daerah akan sangat mempengaruhi proses peresapan air. Semakin besar nilai derajat kemiringan maka akan semakin mudah jumlah air yang meresap ke dalam tanah. Kemiringan lereng ini juga dipengaruhi oleh faktor infiltrasi untuk beberapa jenis kemiringan. Daerah penelitian ini memiliki nilai kemiringan yang bervariasi seperti yang dapat dilihat pada Gambar 9. Daerah dengan kemiringan lereng lebih dari $40^{\circ}$ terdapat pada daerah Kejajar, sedangkan daerah dengan kemiringan lereng 20-40 terdapat pada daerah dengan morfologi puncak gunungapi seperti di G. Sumbing dan G. Sundoro. Sedangkan daerah yang relatif datar terdapat pada bagian tengah yaitu pada bagian Kecamatan Wonosobo yang memiliki kemiringan lereng $<5^{\circ}$.

Variasi derajat kemiringan lereng pada daerah penelitian ini dapat diklasifikasikan menjadi 5 daerah. Daerah pertama memiliki nilai kemiringan $<5^{\circ}$ yang berada di bagian tengah daerah penelitian yaitu pada Kecamatan Wonosobo. Daerah ini memiliki skor 2.

Daerah kedua memiliki kemiringan lereng 5-10 . Setelah dikalikan dengan nilai bobot dihasilkan skor 4. Daerah tersebut terletak di daerah Kretek dan Garung. Daerah 
ketiga dengan kemiringan lereng sebesar $10-20^{\circ}$ berada pada daerah Watumalang. Daerah tersebut memiliki skor 6 setelah dikalikan dengan nilai bobot. Daerah keempat dengan kemiringan lereng sebesar $20-40^{\circ}$ berada di daerah puncak gunung api yaitu pada G. Sundoro dan G. Sumbing, dan juga berada di daerah Kejajar yang sebagian termasuk ke dalam daerah Pegunungan Dieng. Daerah ini memiliki skor 8.

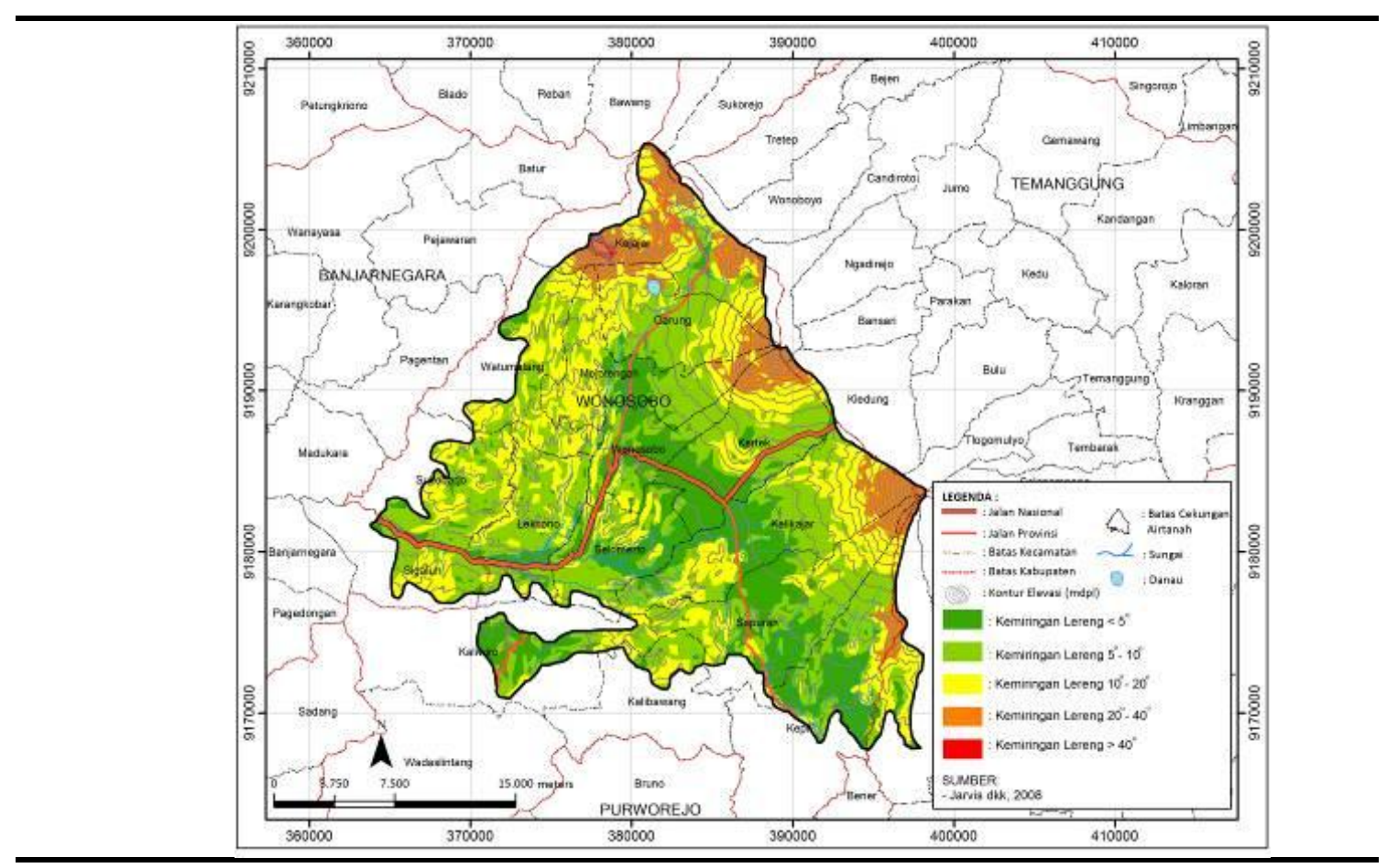

Gambar 9. Peta Kemiringan Lereng

Daerah kelima dengan kemiringan lereng sebesar $<40^{\circ}$ terdapat di sebagian kecil dari sebelah barat daerah Kejajar. Daerah ini memiliki skor 10. Hasil perhitungan dapat dilihat pada Tabel 12 dan disajikan dalam Gambar 10.

Tabel 12. Perhitungan Skor Parameter Kemiringan Lereng.

\begin{tabular}{llll}
\hline Kemiringan Lereng $\left({ }^{\circ}\right)$ & Nilai Peringkat & Nilai Bobot & Skor \\
\hline$>40$ & 5 & 2 & 0 \\
$20-40$ & 4 & 2 & 8 \\
$10-20$ & 3 & 2 & 6 \\
$5-10$ & 2 & 2 & 4 \\
$<5$ & 1 & 2 & 2 \\
\hline
\end{tabular}

\section{Parameter Kedalaman Muka Airtanah Dangkal}

Kedalaman muka airtanah merupakan jarak minimun muka tanah terhadap permukaan airtanah. Semakin dalam muka airtanah maka air akan lebih mudah lolos atau bermigrasi ke tempat. Semakin dangkal muka airtanah maka aka semakin menunjukkan ciri-ciri daerah imbuhan airtanah. Parameter kedalaman muka airtanah merupakan parameter keempat dengan nilai terendah yaitu memiliki nilai satu. Nilai satu ini menunjukkan bahwa parameter ini adalah parameter yang paling kurang berpengaruh dalam penelitian ini dan juga menunjukkan bahwa parameter ini adalah parameter yang paling kurang spesifik dalam menunjukkan daerah imbuhan airtanah. 


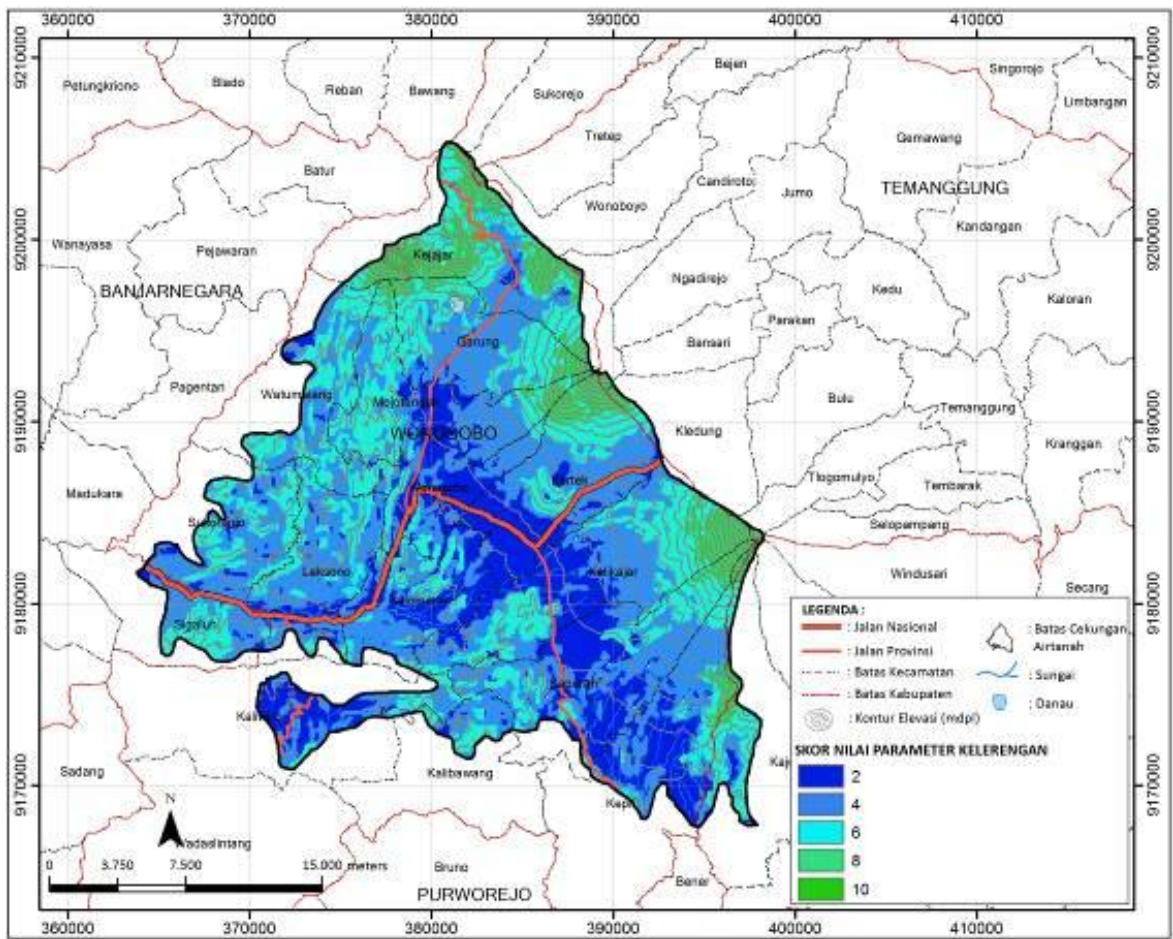

Gambar 10. Skor Nilai Parameter Kemiringan Lereng

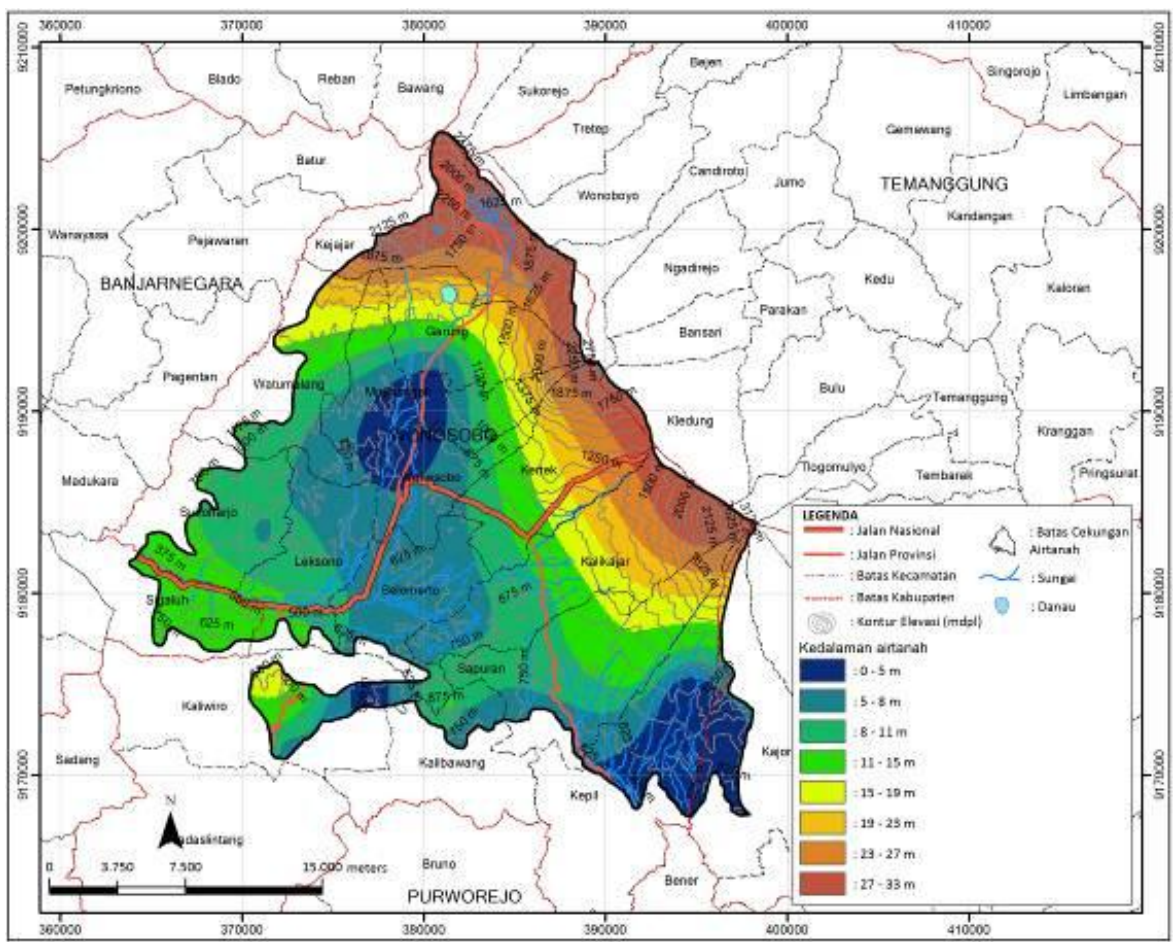

Gambar 11. Peta Kedalaman Muka Airtanah

Berdasarkan klasifikasi Danaryanto, dkk. (2007), daerah penelitian dapat dibagi menjadi lima daerah. Daerah dengan kedalaman $<5$ m dengan nilai skor 1 (Gambar 11) 
yang terdapat di Kecamatan Mojotengah, sebagian daerah Kecamatan Wonosobo, Kecamatan Kepil dan Kecamatan Kajoran. Daerah dengan kedalaman 5-10 m terdapat di Kecamatan Selomerto dan Leksono. Daerah ini memiliki nilai peringkat 2 sehingga setelah dikalikan dengan nilai bobot dapat menghasilkan skor 2. Daerah lainnya memiliki kedalaman 10-20 m yaitu terdapat di daerah Kecamatan Sigaluh, Kecamatan Garung, sebelah barat Kecamatan Kalikajar dan Kecamatan Kertek. Daerah tersebut memiliki nilai peringkat 3 . Nilai tersebut selanjutnya dikali dengan nilai bobot 1 dan menghasilkan skor 3. Daerah dengan kedalaman 20-30 m yang terdapat di daerah Kejajar, lereng Gunung Sumbing dan Gunung Sindoro dengan nilai skor 4 dan pada kedalaman $>30 \mathrm{~m}$ yang terdapat di wilayah utara daerah penelitian memiliki nilai skor 5. Hasil perhitungan dapat dilihat pada Tabel 13 dan disajikan dalam bentuk peta pada Gambar 12.

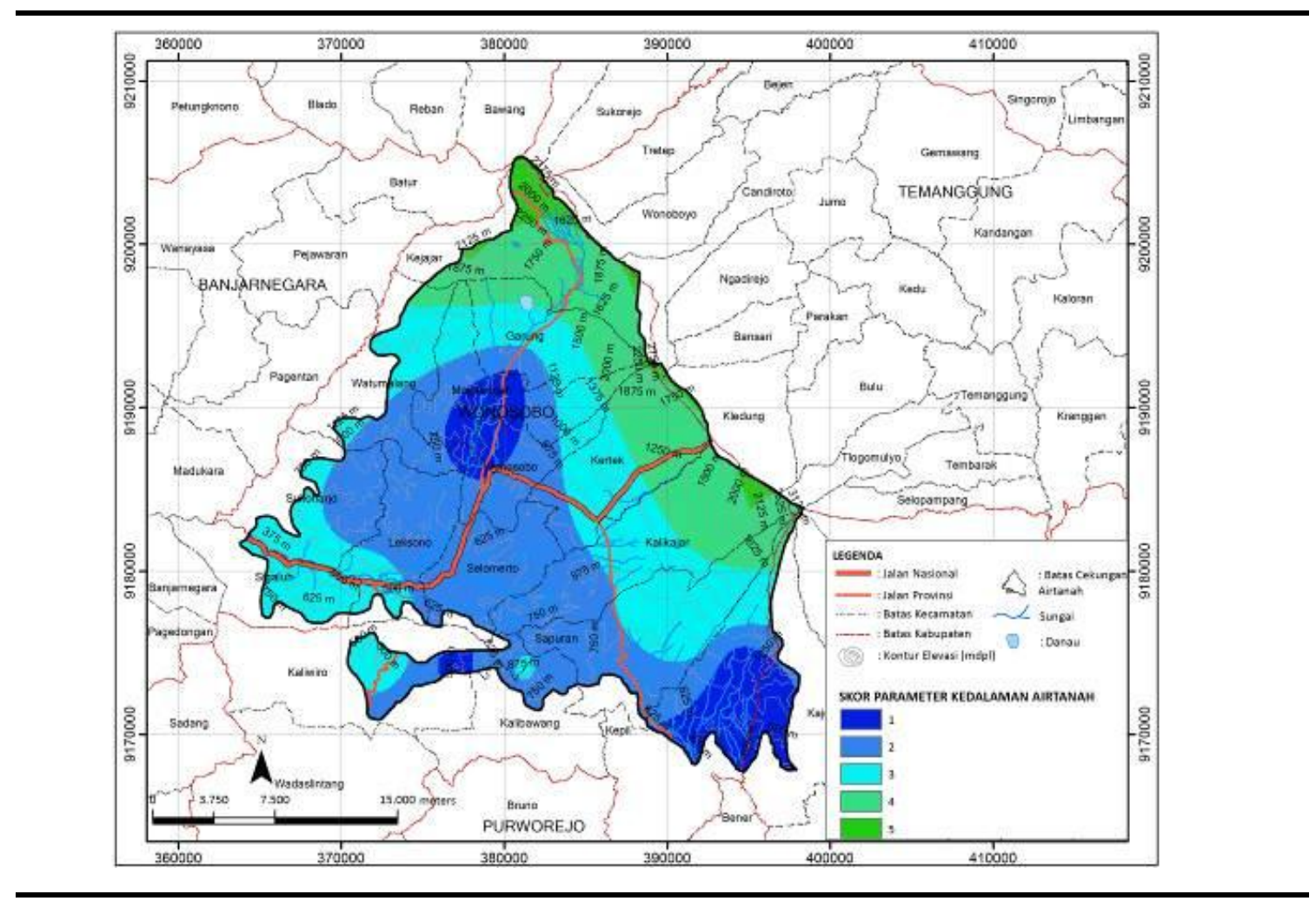

Gambar 12. Skor Nilai Parameter Kedalaman Muka Airtanah

Tabel 13. Perhitungan Skor Parameter Kedalaman Muka Airtanah Tidak Tertekan.

\begin{tabular}{llll}
\hline Kedalaman Muka Airtanah Tidak Tertekan (m) & Nilai Peringkat & Nilai Bobot & Skor \\
\hline$>30$ & 5 & 1 & 5 \\
$20-30$ & 4 & 1 & 4 \\
$10-20$ & 3 & 1 & 3 \\
$5-10$ & 2 & 1 & 2 \\
$<5$ & 1 & 1 & 1 \\
\hline
\end{tabular}

\section{Peta Zona Imbuhan dan Lepasan Airtanah}

Berdasarkan hasil penggabungan beberapa peta parameter maka nilai-nilai yang diperoleh dapat dijadikan acuan dalam mengklasifikasikan zona imbuhan dan zona 
lepasan. Pembobotan yang dihasilkan dalam peta ini memiliki rentang nilai antara 37 sampai 64 (Gambar 13). Apabila dilihat dari klasifikasi yang dibuat oleh Danaryanto, dkk. (2007), keseluruhan daerah memiliki klasifikasi daerah imbuhan utama karena memiliki nilai akhir di atas 33. Oleh sebab itu, diperlukan klasifikasi lebih detil dengan modifikasi seperti pada Tabel 7.

Nilai-nilai pembobotan yang dihasilkan dapat dibagi menjadi dua jenis yaitu daerah imbuhan dan daerah lepasan. Daerah lepasan memiliki nilai akhir dari hasil pembobotan antara 37-54. Daerah lepasan berdasarkan hasil pembobotan terletak di daerah Kecamatan Sigaluh, Kecamatan Leksono, Kecamatan Sukoharjo, Kecamatan Kaliwiro, Kecamatan Watumalang, Kecamatan Wonosobo, sebagian daerah bagian barat Kecamatan Kajoran, bagian barat daya dari Kecamatan Kepil, sebelah barat Kecamatan Garung, Kecamatan Sapuran dan Kecamatan Mojotengah. Daerah ini terdapat di daerah dengan morfologi bergelombang miring vulkanik. Daerah ini terdiri dari berbagai jenis tanah penutup seperti regosol, andosol, mediteran, organosol, litosol dan andosol.

Daerah imbuhan berdasarkan hasil pembobotan terletak di lereng G. Sumbing, G. Sundoro dan Kecamatan Kejajar (Gambar 14). Daerah ini memiliki nilai pembobotan 55-64. Daerah ini termasuk ke dalam satuan geomorfologi pegunungan sangat terjal vulkanik tersebut yang merupakan ciri khusus dari daerah imbuhan airtanah. Daerah ini memiliki nilai pembobotan tinggi karena terdiri dari litologi breksi vulkanik dan tanah berupa regosol yang cenderung mudah untuk menyalurkan air dikarenakan porositas dan permeabilitas yang baik. Selain itu, daerah penelitian juga termasuk ke dalam klasifikasi lereng antara $20^{\circ}-40^{\circ}$ dan lereng lebih dari $40^{\circ}$.

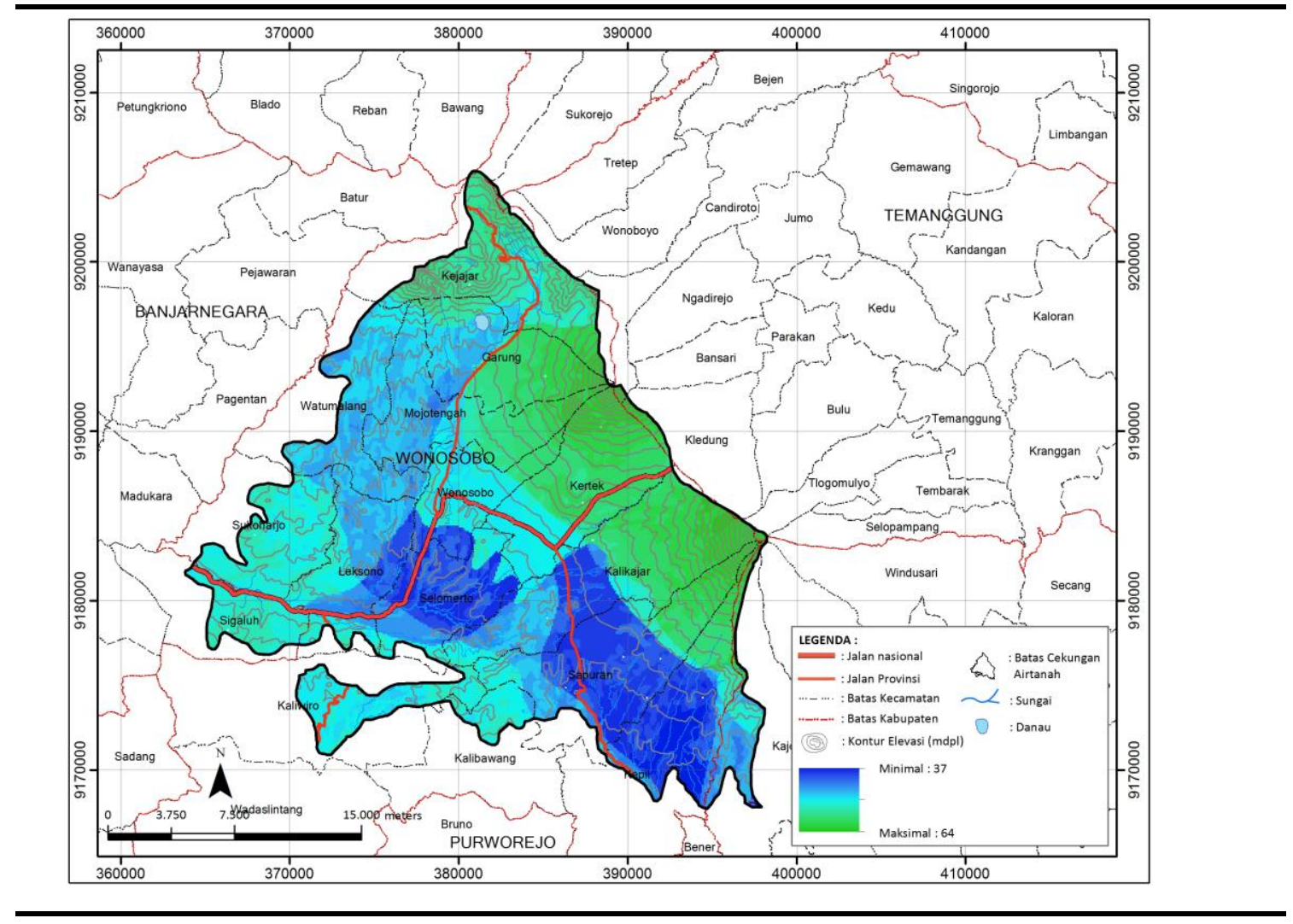

Gambar 13. Hasil Metode Skoring 


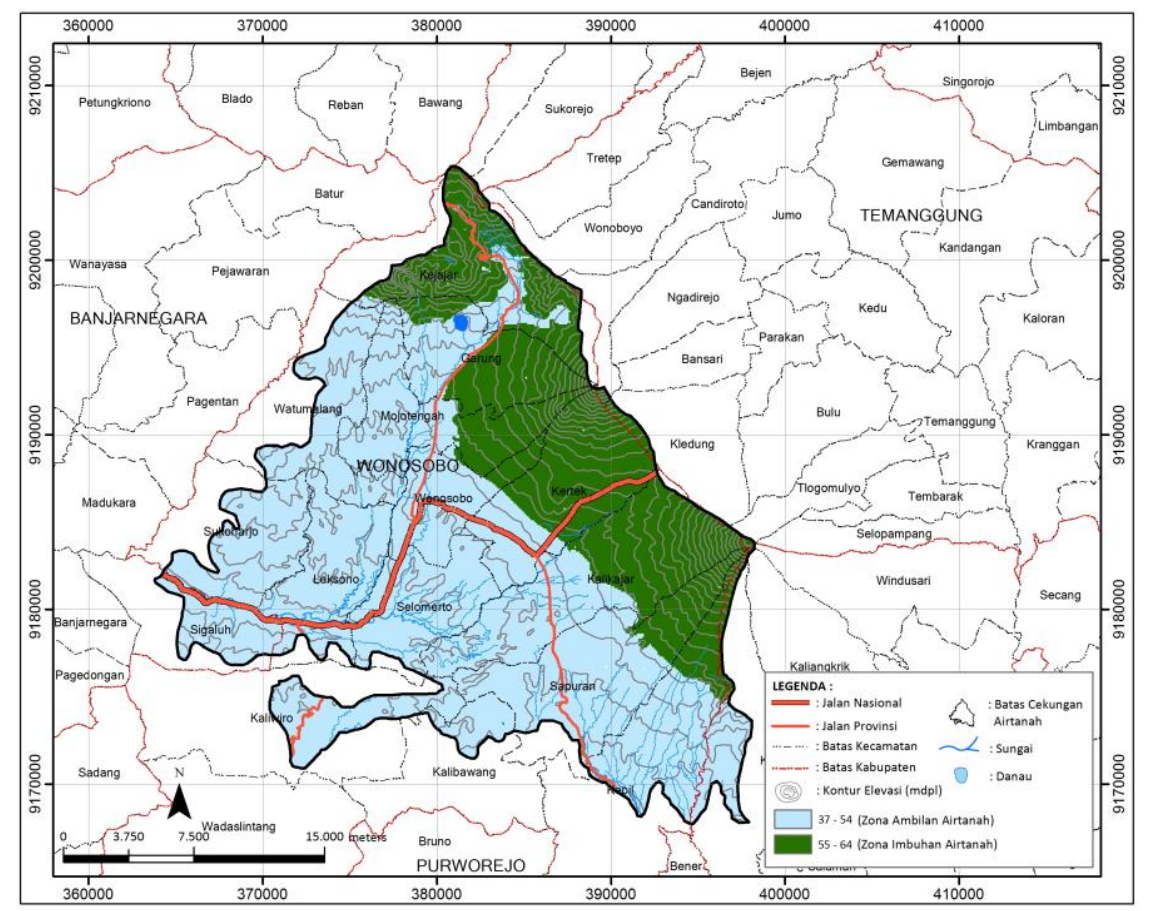

Gambar 14. Zonasi Area Imbuan dan Ambilan Airtanah

\section{Kesesuaian dengan peta RTRW}

Setelah dilakukan klasifikasi zona imbuhan utama maka dilanjutkan untuk menyesuaikan lahan yang sesuai dengan zona-zona tersebut. Hal ini dilakukan untuk menjaga sumberdaya air yang terdapat pada daerah CAT Wonosobo. Pada bagian daerah imbuhan, tata guna lahan belum semua area memiliki fungsi tata guna lahan yang tepat pada daerah tersebut. Tata guna lahan yang sesuai berupa kawasan hutan, sedangkan tata guna lahan yang tidak sesuai berupa permukiman dan perkebunan karena mengurangi air yang masuk ke dalam tanah, berbeda dengan hutan yang didominasi oleh tanaman akar tunggang. Selain itu, perkebunan sering menggunakan pestisida yang akan masuk ke dalam tanah. Hal ini dikhawatirkan berpengaruh terhadap kualitas air.

Pada daerah imbuhan sebagian daerah dijadikan sebagai daerah permukiman. Saat ini hal tersebut masih dalam jumlah yang terbatas, tetapi jika tidak dikendalikan kedepannya mempengaruhi kuantitas dan kualitas air sehingga Pemda (Pemerintah Daerah) perlu mengawasi perkembangan pembangunan terutama pada area imbuhan utama. Tata guna lahan pada daerah lepasan airtanah digunakan sebagai sawah irigasi oleh warga. Keadaan tersebut tidak terlalu berpengaruh terhadap kualitas dan kuantitas airtanah.

Kondisi RTRW yang digunakan oleh Pemda pada CAT sebagian besar sudah sesuai dengan tempatnya. Misalnya pada daerah imbuhan utama direncanakan menjadi kawasan hutan lindung, kawasan lindung yang dikelola masyarakat dan kawasan hutan. Perencanaan yang sudah sesuai ini dapat ditingkatkan dengan sosialisasi kegiatankegiatan untuk konservasi airtanah pada zona imbuhan dan zona lepasan di daerah CAT 
Wonosobo ini. Sosialisasi tersebut diantaranya adalah menginformasikan mengenai penggunaan airtanah pada daerah lepasan airtanah. Penggunaan airtanah untuk keperluan di daerah yang belum terjangkau oleh pelayanan air bersih PDAM diizinkan memanfaatkan airtanah pada sistem akuifer tertekan dengan debit maksimum 2,15-7,25 L/det maksimum pada kedalaman 55-155 m (Dinas ESDM, 2007) dan jarak minimum antar sumur (2R) 90-165 m dan konstruksi sumur dibangun sesuai dengan SNI No. 036422-2000.

\section{KESIMPULAN}

Dari hasil kajian penelitian penentuan zona imbuhan dan zona lepasan airtanah pada CAT Wonosobo diperoleh kesimpulan sebagai berikut, urutan parameter dari yang paling berpengaruh adalah kelulusan batuan, curah hujan, jenis tanah penutup, kemiringan lereng dan kedalaman muka air tanah tidak tertekan. Kelima parameter tersebut sangat berpengaruh dalam membentuk zona imbuhan seperti kelulusan batuan yang mempengaruhi jumlah air yang masuk ke dalam lapisan batuan akibat permeabilitas dari batuan dan curah hujan yang mempengaruhi jumlah pasokan air yang masuk. Peta pembobotan yang dihasilkan memiliki nilai antara 37-64 dan dapat diklasifikasikan menjadi daerah imbuhan dan daerah lepasan airtanah. Daerah lepasan berdasarkan hasil pembobotan terletak di Kecamatan Sigaluh, Kecamatan Leksono, Kecamatan Sukoharjo, Kecamatan Kaliwiro, Kecamatan Watumalang, Kecamatan Wonosobo, sebagian daerah bagian barat Kecamatan Kajoran, bagian barat daya dari Kecamatan Kepil, sebelah barat Kecamatan Garung, Kecamatan Sapuran dan Kecamatan Mojotengah dengan nilai akhir 37-54. Sedangkan daerah imbuhan berdasarkan hasil pembobotan terletak di Lereng G. Sumbing, G. Sindoro dan Kecamatan Kejajar. Daerah ini memiliki nilai akhir pembobotan antara 55-64. Pemerintah daerah perlu mengawasi perkembangan pembangunan terutama pada area imbuhan utama dengan menjadikan penentuan daerah imbuhan dan lepasan airtanah sebagai acuan RTRW. Rekomendasi untuk daerah imbuhan tetap menjaga daerah tersebut sebagai kawasan hutan lindung. Pada daerah lepasan airtanah harus diawasi dalam penggunaan airtanahnya yaitu penggunaan airtanah untuk keperluan di daerah yang belum terjangkau oleh pelayanan air bersih PDAM diizinkan memanfaatkan airtanah pada sistem akuifer tertekan dengan debit 2,15-7,25 L/det, maksimum pada kedalaman 55-155 m (Dinas ESDM, 2007) dan jarak minimum antar sumur (2R) 90165 m dan konstruksi sumur dibangun sesuai dengan SNI No. 03-6422-2000.

\section{UCAPAN TERIMA KASIH}

Penulis mengucapkan terima kasih kepada Pemerintah Provinsi Jawa Tengah cq Dinas Energi dan Sumber Daya Mineral melalui studi Konservasi pada Cekungan Airtanah Wonosobo Tahun 2016.

\section{DAFTAR PUSTAKA}

Badan Standarisasi Nasional. 2000. Spesifikasi Konstruksi Sumur Bor Produksi Air Tanah Untuk Kapasitas 150 Liter Per Menit Sampai Dengan 300 Liter Per Menit.

Bakosurtanal. 2004. Peta Rupa Bumi Indonesia Provinsi Jawa Tengah dan Daerah Istimewa Yogyakarta.

Bappeda Kabupaten Banjarnegara. 2011. Peta Jenis Tanah Kabupaten Banjarnegara. Banjarnegara.

Bappeda Kabupaten Magelang. 2012. Peta Jenis Tanah Kabupaten Magelang. Magelang.

Bappeda Kabupaten Wonosobo. 2011. Peta Jenis Tanah Kabupaten Wonosobo. Wonosobo 
CGIAR-CSI. 2004. SRTM Data Search, http://srtm.csi.cgiar.org/SELECTION/inputCoord.asp. Online akses 9 January 2016.

Climate-data.org. 2012. Iklim: Grafik Iklim, http://id.climate-data.org/location/329020. Online akses 08 November 2015.

Danaryanto, Titomiharjo H., Setiadi H., Siagian Y. 2007. Kumpulan Pedoman Teknis Pengelolaan Airtanah. Badan Geologi: Bandung.

Dinas Energi Sumber Daya Mineral/ESDM. 2007. Survei Potensi Airtanah di Wilayah Cekungan Airtanah (CAT) Wonosobo. ESDM: Semarang.

Dinas Energi Sumber Daya Mineral/ESDM. 2015. Penyusunan Zona Pemanfaatan dan Konservasi Airtanah pada Cekungan Airtanah (CAT) Wonosobo. ESDM: Semarang.

Fenta, A.A., Kifle, A., Gebreyohannes, T., and Hailu, G. 2015. Spatial Analysis of Groundwater Potential Using Remote Sensing and GIS-based Multi-Criteria Evaluation in Raya Valley, northern Ethiopia. Hydrogeology Journal Vol 23: 195-206.

Ganapuram, S., Kumar, G.T.V., Krishna, I.V.M., Kahya, E., and Demirel, M.C. 2009. Mapping of groundwater potential zones in the Musi Basin Using Remote Sensing Data and GIS. Advances in Engineering Software Vol.40 (7): 506-518.

Magesh, N.S., Chandrasekar, N., and Soundranayagam, J.P. 2012. Delineation of Groundwater Potential Zones in Theni District, Tamil Nadu, using remote sensing, GIS and MIF Techniques. Geosciences Frontiers 3 (2) (2012) 189-196. http://dx.doi.org/10.1016/j.gsf.2011.10.007

Malekmohammadi, B., Mehrian M.R., and Jafari, H.R. 2012. Site Selection for Managed Aquifer Recharge using Fuzzy Rules: Integrating Geograhical Information System (GIS) tools and Multi-Criteria Decision Making. Hydrogeology Journal Vol 12 (7): 1393-1405.

Manap, M.A., Sulaiman, W.N.A., and Ramli, M.F. 2013. A knowledge-driven GIS modeling technique for groundwater potential mapping at the Upper Langat Basin, Malaysia. Arabian Journal of Geoscience Vol. 6 (5): 1621-1637.

Nolan, B.T., Baehr, A.L., and Kauffman, L.J. 2003. Spatial Variability of Groundwater Recharge and Its Effect on Shallow Groundwater Quality in Southern New Jersey. Vadose Zone Journal 2: 677-691.

Peraturan Menteri ESDM No. 13 Tahun 2009. Pedoman Penyusunan Rancangan Penetapan Cekungan Airtanah.

Senayake, I.P, Dissanayake, D.M.D.O.K., Mayadunna, B.B., and Weerasekera, W.I. 2016. An Approach to Delineate Groundwater Recharge Potential Sites in Ambalantota, Sri Lanka using GIS techniques, Geosciences Frontiers 7: 115-124 http://dx.doi.org/10.1016/j.gsf.2015.03.002.

Setiadi, H. 2005. Peta Cekungan Airtanah Provinsi Jawa Tengah Skala 1:100.000, Kerjasama Dinas Pertambangan dan Energi Provinsi Jawa Tengah dengan Direktorat Tata Lingkungan Geologi dan Kawasan Pertambangan.

Shukla, S.M. 2014. Spatial Analysis for groundwater potential zones using GIS and Remote Sensing in the Tons Basin of Allahabad District, Uttar Pradesh (India). Proc. Natl. Acad. Sci, India Sect. A Phys. Sci Vol 84 (4): 587-593.

Steinel A., Schelkes, K., Subah A., and Himmelsbach T. 2016. Spatial Multi-Criteria Analaysis for Selecting Potential Sites for Aquifer Recharge Via Harvesting and Infiltration of Surface Runoff in North Jordan. Hydrogeology Journal Vol 24: 1753-1774.

Todd, D. K. and Mays, L. W. 2005. Groundwater Hydrology, $3^{\text {rd }}$ Ed. John Willey and Sonc.inc: New York.

Yeh, H.F., Cheng, Y.S., Lin, H.I, and Lee, C.H. 2016. Mapping groundwater recharge potential zone using a GIS Approach in Hualian River, Taiwan, Sustainable Environment Research 26: 33-43 http://dx.doi.org/10.1016/j.serj.2015.09.005. 